\title{
Ohra-hernekokoviljasäilörehun ja loppukasvatuksen väkirehuintensiteetin vaikutus hereford-sonnien tuotantoon
}

\author{
Merja Manninen $^{1)}$, Arja Nykänen ${ }^{2)}$, Lauri Jauhiainen ${ }^{1)}$ ja Marjatta Suvitie ${ }^{3)}$ \\ ${ }^{1)}$ MTT, 31600 Jokioinen, merja.manninen@mtt.fi, lauri.jauhiainen@mtt.fi \\ ${ }^{2)}$ MTT, 51900 Juva, arja.nykanen@mtt.fi \\ ${ }^{3)}$ MTT, 71750 Maaninka, marjatta.suvitie@mtt.fi
}

\section{Tiivistelmä}

Seoskasvustoista valmistettujen ns. kokoviljasäilörehujen käyttö naudoille on lisääntynyt, mm. koska ne voidaan korjata säilörehun korjuukalustolla ja kasvustot mahdollistavat karjanlannan sijoituksen pelloille. Sonnien loppukasvatuksen väkirehuruokintaintensiteettiä selvittäneen hankkeen ensimmäisessä kokeessa vapaa väkirehuruokinta 3 kk ennen teurastusta paransi hereford (hf)-sonnien kasvua merkitsevästi. Tämä tutkimus selvitti ohra-hernekokoviljasäilörehun tuotantovaikutukset hf-sonnien loppukasvatuksessa, kun sonnit saivat kotoista väkirehuseosta loppukasvatusvaiheessa joko 3 tai $6 \mathrm{~kg}$ $\mathrm{KA} / \mathrm{pv}$.

Kokeeseen otettiin 32 hf-sonnia, jotka painoivat kokeen alkaessa keskimäärin $271 \mathrm{~kg}$. Koe tehtiin MTT:n emolehmänavetalla, jossa eläimet olivat neljän eläimen karsinoissa. Koemalli oli $2 * 2$ faktoriaalinen, faktoreina karkearehu (nurmisäilörehu, NSR vs. ohraherneseossäilörehu, OHSR) ja loppukasvatuksen väkirehuintensiteetti (niukka, N vs. runsas, R). Esikuivatun NSR:n kasvusto niitettiin niittomurskaimella, paalattiin silppuavalla pyöröpaalaimella ja käärittiin muoviin. Seoskasvusto korjattiin ohran taikinatuleentumisasteella kaksoissilppurilla laakasiiloon. Rehujen säilöntään käytettiin AIV 2 Plus -liuosta. Väkirehu oli ohra-kaura-valkuaistiiviste-seos, jonka valkuaistavoite oli $180 \mathrm{~g} / \mathrm{kg}$ KA. Sonnit saivat väkirehua ensimmäiset 56 pv 2,0, seuraavat 84 pv 2,5 ja loppukasvatuksen ajan joko 3,0 tai 6,0 kg KA/pv. Eläimet saivat kivennäis- ja vitamiinitäydennyksen. Dieetin sulavuus määritettiin neljästi kokeen aikana. Sonnit teurastettiin Lihakunnan Kuopion teurastamossa.

NSR:n apilapitoisuus oli 5 \% KA:sta. OHSR:n KA-sato oli $8600 \mathrm{~kg} / \mathrm{ha}$ ja hernepitoisuus 13,5 \% KA:sta. NSR:n KA-pitoisuus oli keskimäärin $253 \mathrm{~g} / \mathrm{kg}$ ja D-arvo 72,0 \%. KA-kilo sisälsi raakavalkuaista 178 g ja OIV:sta 88 g. Vastaavat luvut OHSR:lle olivat 257 g/kg, 66,5 \%, 155 g ja 85 g. NSR:n voihappopitoisuus oli 9,2 g/kg KA. Väkirehun KA-kilo sisälsi raakavalkuaista $183 \mathrm{~g}$ ja energiaa 1,09 RY. Koe kesti keskimäärin 269 pv. N-ruokinnat täyttivät luonnonmukaisen tuotannon vaatimuksen väkirehu-karkearehu-suhteesta. NSR-ruhojen keskimääräiseksi teuraspainoksi muodostui $339 \mathrm{~kg}$ ja OHSR-ruhojen $320 \mathrm{~kg}$. R-sonnien kasvu loppujaksolla oli N-sonneja parempaa, erityisesti NSR-ruokinnalla, mutta ero intensiteetin välillä ei ollut merkitsevä ( $\mathrm{P}=0,10,1511$ vs. 1273 g/pv). NSR-sonnit kasvoivat keskimäärin 273 g/pv paremmin kuin OHSR-sonnit. Teuras-\% oli keskimäärin 53,4. NSR-ruhot luokitettiin lihakkaammiksi kuin OHSR-ruhot, rasvaisuudessa ero oli suuntaa antava. Loppukaudella R-ruokinta heikensi orgaanisen aineen, proteiinin ja ND-kuidun sulavuutta, eniten NDkuidun.

R-ruokinta loppukasvatusvaiheessa tehosti hieman sonnien kasvua, mutta ei vaikuttanut haitallisesti eläinten terveyteen. Herneen osuus seoskasvustossa oli melko alhainen, mikä oli seuraus herneen kylvömäärästä. OHSR:lla ei päästy NSR:a vastaaviin tuotantotuloksiin. Merkittävin syy tähän oli seosrehun nurmisäilörehua alhaisempi sulavuus eli D-arvo.

Avainsanat: herne, lihan laatu, naudanlihantuotanto, ruokinta, seossäilörehu, sonni 


\section{Johdanto}

Teuraaksi kasvatettavien sonnien ruokinnan perusrehu on maassamme perinteisesti ollut nurmisäilörehu. Viime aikoina myös kokoviljasäilörehun ja seoskasvustoista valmistettujen säilörehujen käyttö on lisääntynyt. Palkokasvi-kokoviljasäilörehu voidaan korjata säilörehun korjuukalustolla, jolloin tilan ei tarvitse investoida puintikalustoon. Yksivuotiset kasvustot mahdollistavat karjanlannan sijoituksen pelloille ja peltojen parannustoimenpiteet on mahdollista tehdä keväällä ennen kasvustojen kylvöä. Erityisesti luonnonmukaisessa tuotannossa typpeä sitovien yksivuotisten seoskasvustojen käyttö on lisääntynyt, sillä runsaasti vihermassaa tuottavat virnat ja vihantarehuherne lisäävät kokoviljasäilörehun satoa (Nykänen ym. 2001) ja varsinkin herneet parantavat sen valkuaispitoisuutta ja sulavuutta (Syrjälä-Qvist 1986, Joki-Tokola ym. 2002, Kiljala ym. 2004).

Sonnien loppukasvatuksen väkirehuruokintaintensiteettiä selvittävän hankkeen ensimmäisessä osakokeessa seurattiin vapaan väkirehuruokinnan, noin 100 päivää ennen teurastusta, vaikutuksia tuotantoon, ruhon ja lihan laatuun, eläinten terveyteen, hyvinvointiin ja tuotannon talouteen. Hereford (hf)-sonnit saivat nurmisäilörehua vapaasti ja väkirehuna oli joko täysrehu tai ohra-kaurarypsirouheseos. Vapaa väkirehuruokinta kolme kuukautta ennen teurastusta paransi sonnien kasvua merkitsevästi (Manninen ym. 2004). Väkirehutyypillä ei sen sijaan ollut vaikutusta tuotantotuloksiin. Kaikki sonnit rasvoittuivat. Ruokinnat eivät vaikuttaneet lihan aistinvaraiseen laatuun. Vapaa väkirehuruokinta vaikutti merkittävästi seerumin kokonaisproteiini- ja ureapitoisuuksiin. Kokonaisproteiinipitoisuudessa vaikutus oli ohimenevä, mutta ureapitoisuudet pysyivät koholla kokeen loppuun saakka (Pösö ym. 2004). Vapaa täysrehuruokinta aiheutti eläimille lievää stressiä, mikä näkyi seerumin kortisolipitoisuuksien nousuna ja nousevana tendenssinä juoksutusmahan stressiproteiinipitoisuuksissa. Sen sijaan ruokinnalla ei ollut vaikutusta pötsin happamuuteen (Koho ym. 2004). Sorkkaterveyteen vapaa väkirehuruokinta ei vaikuttanut haitallisesti, kun arvioitiin eläinten ontumista, sorkkaluun asentoa ja martosorkan silmämääräisesti havaittavia muutoksia. Vapaan väkirehuruokinnan kesto oli oletettavasti liian lyhyt aika aiheuttamaan selviä muutoksia sorkkiin. Myös pääosin pehmeä alusta, hyvät liikuntamahdollisuudet ja ND-kuidun kohtalaisen suuri osuus ruokinnassa vaikuttivat hyvään sorkkaterveyteen (Soveri ym. 2004). Edellä kuvatun kokeen tulosten perusteella ei voida antaa yleispäteviä suosituksia taloudellisimmasta ruokintatavasta, mutta ne antavat kuitenkin viitteitä intensiivisen ruokinnan edullisuudesta, mikäli väkirehun hinta on kohtuullinen (Pihamaa ym. 2004).

Tutkimushankkeen toinen osakoe, jonka tulokset tässä esitetään, selvitti ohra-hernekasvustosta valmistetun seossäilörehun tuotantovaikutukset hf-sonnien loppukasvatuksessa, kun sonnit saivat kotoista väkirehuseosta loppukasvatusvaiheessa joko 3 tai 6 kuiva-ainekiloa päivässä.

\section{Aineisto ja menetelmät}

\section{Eläinaines ja tuotanto-olosuhteet}

Kokeeseen otettiin 32 ajalla 13.3.-5.6.2002 syntynyttä hf-sonnivasikkaa, isinä hf-sonnit Koskis Noak (13), Thorsvik Kentauri (12) ja Innilän Leevi (7). Vasikoiden kasvu syntymästä kokeen alkuun oli keskimäärin 1244 g/pv. Ennen koetta vasikat olivat emineen laitumella eivätkä saaneet väkirehua. Koe alkoi 11.10.2002 vasikoiden ollessa keskimäärin 184 (SD 18,1) päivän ikäisiä ja 271 (SD 29,2) kiloisia. Koe tehtiin MTT:n emolehmänavetalla, jossa eläimet olivat neljän eläimen karsinoissa. Eläimet ulkoilivat jaloittelutarhoissa karsinoiden kuivituksen ajan ja ne punnittiin säännöllisesti.

\section{Rehut, ruokinta ja teurastus}

Ruokintakokeen koemalli oli 2*2 faktoriaalinen, faktoreina karkearehu (nurmisäilörehu, NSR vs. ohraherneseossäilörehu, OHSR) ja loppukasvatuksen väkirehuintensiteetti (niukka, $\mathrm{N}$ vs. runsas, R). Esikuivatun säilörehun kasvusto niitettiin 11.-12.6.2002 (timotei-nurminata-apila -kasvusto 65-30-5 \% siemenseoksessa) niittomurskaimella, paalattiin silppuavalla pyöröpaalaimella ja käärittiin muoviin. Nurmikasvuston lannoitukseen käytettiin Nurmen NK-lannoitetta 440 kg/ha, josta 88 kg N/ha. Ohra (Erkki) -herne (Arvika, pitkävartinen vihantarehuherne) -siemenseos kylvettiin nurmen suojakasviksi 25.5.2002 käyttäen herneen siementä $29 \mathrm{~kg} / \mathrm{ha}$ ja ohran siementä $100 \mathrm{~kg} / \mathrm{ha}$. Siementen kylvösuhteen perusteena oli vallitseva tukipolitiikka, jonka mukaan siemenseoksessa palkokasvien osuus ei saanut ylittää $30 \%$, jotta pelto säilyi CAP-tuen piirissä. Nurmen suojakasvina käytettävässä kasvustossa ei hernettä voi olla enempää, koska herneen lakoherkkyys voi vaarantaa alla oleva nurmen onnistumista. Seoskasvuston lannoitukseen käytettiin karjanlantaa $40 \mathrm{~m}^{3} / \mathrm{ha}$ ja Suomensalpietaria $200 \mathrm{~kg} / \mathrm{ha}$, josta 52 
kg N/ha. Seoskasvusto korjattiin ohran taikinatuleentumisasteella 2.-5.8.2002 kaksoissilppurilla laakasiiloon. Varsinkin kasvun alkuvaiheessa ohra varjosti hernettä voimakkaasti. Molempien säilörehujen säilöntään käytettiin AIV 2 Plus -liuosta (760 g muurahaishappoa/kg ja 55 g ammoniumformiaatti/kg). Molemmista säilörehukasvustoista otettiin näytteet suoraan pellolta kasvustosta sadonkorjuuhetkellä sekä ohrahernekasvustosta myös kolme viikkoa ennen sadonkorjuuta. Ruokinnassa olleista säilörehuista analysoitiin MTT:llä kuiva-aine (KA), tuhka, raakaproteiini, ND-kuitu (Van Soest ym. 1991), tärkkelys seossäilörehusta (McCleary ym. 1994) ja orgaanisen aineen in vitro sellulaasisulavuus (Friedel 1990).

Väkirehuseos oli jauhettu ohra-kaura-valkuaistiiviste-seos (54-30-16 \% KA:sta), jonka valkuaistavoite oli $180 \mathrm{~g} / \mathrm{kg} \mathrm{KA}$. Valkuaistiiviste sisälsi rypsirouhetta $70 \%$, rypsipuristetta $24 \%$ ja melassia $6 \%$ tuorepainosta. Sonnit saivat väkirehua ensimmäiset 56 päivää 2,0 (alkujakso, A), seuraavat 84 päivää 2,5 (keskijakso, K) ja loppukasvatuksen (L, keskimäärin 129 päivää) ajan joko 3,0 tai 6,0 kg KA päivässä. Eläimet saivat kivennäis- ja vitamiinitäydennyksen (Seleeni Hertta-Minera Muro; Ca 200, P 50, Na 70 ja Mg 70 g/kg ja Xylitol ADE-Vita; A 2000000 ja D 400000 ky/kg, E 1 000 ja Se $20 \mathrm{mg} / \mathrm{kg}$ ) ja vettä vapaasti. Väkirehun rehuarvo laskettiin raaka-ainekoostumuksen perusteella (Tuori ym. 2002). Dieetin sulavuus määritettiin neljästi kokeen aikana, kahdesti keski- ja kahdesti loppujaksolla käyttäen merkkiaineena happoon liukenematonta tuhkaa (European Commission 1971). Sonnit teurastettiin Lihakunnan Kuopion teurastamossa ja ruhot luokitettiin EUROPluokituksen mukaisesti.

\section{Tilastollinen käsittely}

Eläimet jaettiin koon mukaan kahteen lohkoon. Lohkon sisällä eläimet arvottiin neljään karsinaan, joihin kuhunkin kohdistettiin yksi käsittelyistä. Syönti ja sulavuus mitattiin karsinakohtaisesti, jolloin standardia satunnaistettujen täydellisten lohkojen varianssianalyysiä pystyttiin käyttämään käsittelyiden välisten erojen testauksessa. Muut muuttujat mitattiin eläinkohtaisesti. Koska käsittelyt kohdistettiin karsinoihin, ei eläimiin, eläinten välistä vaihtelua ei voitu käyttää virheterminä käsittelyiden välisiä eroja testattaessa. Käytettäväksi valitun tilastollisen mallin on esittänyt mm. Morris (1999) ja siinä virheterminä on lohko 'nested' käsittely -tekijä. Analyysit suoritettiin SAS:n (1999) versiolla 8.2.

\section{Tulokset ja tulosten tarkastelu}

Nurmisäilörehun apilapitoisuus oli 5 \% kuiva-aineesta. Herneohrasäilörehun kuiva-ainesato oli 8600 $\mathrm{kg} / \mathrm{ha}$ ja sadon hernepitoisuus 13,5 \% kuiva-aineesta. Herneen raakavalkuaispitoisuus kolme viikkoa ennen korjuuta oli 219 ja ohran 221 g/kg KA, D-arvot vastaavasti 66,5 ja 67,3 \%. Korjuuhetkellä vastaavat arvot herneelle ja ohralle olivat 153 ja 107 g/kg KA ja 69,3 ja 68,3 \%. Kasvustoista korjuuhetkellä otetuissa raaka-ainenäytteissä heinien raakavalkuaispitoisuus oli 150 g/kg KA ja Darvo 71,3 \% KA, apilalla vastaavasti 227 ja 70,3.

Raaka-ainenäytteiden perusteella herneen D-arvo nousi kolmen viikon aikana ennen sadonkorjuuta. Tämä johtunee herneen kukkien kehittymisestä liduiksi ja paloiksi. Syötetyn rehun D-arvo oli selkeästi alempi (n. 2 \%-yksikköä) kuin raaka-ainenäytteiden, mikä ilmeisesti johtuu korjuutappioista, jyviä ja herneen palkoja ja lehtiä on varissut maahan. Syötetyn rehun korkeampaa raakavalkuaispitoisuutta on vaikea selittää. Mahdollisesti raaka-ainenäytettä ei saatu tarpeeksi edustavasti pellolta. Huomioimatta tukipolitiikkaa, herneen määrän lisääminen kylvöseokseen olisi voinut nostaa seossäilörehun raakavalkuaispitoisuutta, mikä ei kuitenkaan yksiselitteisesti ole lihanaudan tuotantofysiologian kannalta tavoiteltavaa.

Nurmisäilörehu sisälsi runsaasti voihappoa, keskimäärin 9,2 g kuiva-ainekilossa, minkä on voinut aiheuttaa arvioitua niukempi hapon annostelu paaleihin, maan joutuminen rehun sekaan tai paalien siirron yhteydessä tapahtunut muovien rikkoutuminen (Taulukko 1). Koe kesti keskimäärin 269 (SD 28,2) päivää. Yksi NSR-R-sonni puhaltui 25.4.2003 ja poistettiin kokeesta samana päivänä. Yksi OHSR-R-sonni puhaltui ja kuoli 28.10.2002. Muiden eläinten terveys oli moitteeton eikä kliinisiä oireita havaittu. Loppukasvatuskaudella väkirehun osuus syönnistä oli NSR-N-sonneilla 32 \%, NSRR-sonneila 58 \%, OHSR-N-sonnilla 34 \% ja OHSR-R-sonneilla 65 \% (Taulukko 2). Koko koekaudelle laskettuna väkirehuprosentti oli mainituilla käsittelyillä vastaavasti 33, 45, 34 ja 54, toisin sanoen Nruokinnat täyttivät luonnonmukaisen tuotannon vaatimukset väkirehu-karkearehu-suhteesta. Loppukasvatuskaudella OHSR:n syönti muodostui R-ruokinnalla 2,73 kuiva-ainekiloa päivässä pienemmäksi kuin N-ruokinnalla, NSR:lla vastaava ero oli 1,99 kuiva-ainekiloa. 
Taulukko 1. Rehujen kemiallinen koostumus ja rehuarvo.

\begin{tabular}{|c|c|c|c|}
\hline Rehu & Nurmisäilörehu & Herneohraseossäilörehu & Väkirehuseos \\
\hline Näytteiden lukumäärä & 4 & 4 & 3 \\
\hline Kuiva-aine (KA, g/kg) & 253 & 257 & 885 \\
\hline \multicolumn{4}{|l|}{ KA:ssa (g/kg) } \\
\hline Tuhka & 88 & 66 & 38 \\
\hline Raakavalkuainen & 178 & 155 & 183 \\
\hline Neutraali detergentti kuitu & 528 & 494 & 245 \\
\hline Maitohappo & 45 & 62 & \\
\hline Etikkahappo & 17 & 14 & \\
\hline Voihappo & 9,2 & 0,2 & \\
\hline Etanoli & 8 & 6 & \\
\hline Sokerit & 41 & 28 & \\
\hline Tärkkelys & nd & 135 & nd \\
\hline $\mathrm{pH}$ & 4,52 & 3,81 & \\
\hline \multicolumn{4}{|l|}{ Kokonais-N:ssä } \\
\hline Ammonium-N & 94 & 82 & \\
\hline Liukoinen-N & 701 & 653 & \\
\hline D-arvo & 72,0 & 66,5 & \\
\hline Syönti-indeksi & 102 & 94 & \\
\hline \multicolumn{4}{|l|}{ Rehuarvo, /kg KA } \\
\hline RY & 0,99 & 0,88 & 1,09 \\
\hline OIV, g & 88 & 85 & 112 \\
\hline PVT, g & 26 & 10 & 1 \\
\hline
\end{tabular}

${ }^{\mathrm{a}}$ Ei määritetty.

Taulukko 2. Rehujen syönti ja energian saanti.

\begin{tabular}{|c|c|c|c|c|c|c|c|c|c|}
\hline \multirow{2}{*}{$\begin{array}{l}\text { Karkearehu (K) } \\
\text { Intensiteetti (I) }\end{array}$} & \multicolumn{3}{|c|}{ Nurmisäilörehu } & \multicolumn{2}{|c|}{ Seossäilörehu } & & \multicolumn{3}{|c|}{ Merkitsevyys $^{2}$} \\
\hline & \multicolumn{2}{|c|}{ Niukka } & \multirow{2}{*}{$\frac{\text { Runsas }}{2}$} & Niukka & \multirow{2}{*}{$\begin{array}{r}\text { Runsas } \\
2\end{array}$} & & \multirow[t]{2}{*}{$\mathrm{K}$} & \multirow[t]{2}{*}{$\mathrm{I}$} & \multirow[t]{2}{*}{$\mathrm{K} * \mathrm{I}$} \\
\hline Ryhmiä & & 2 & & 2 & & SEM $^{1}$ & & & \\
\hline Karkearehu, kg KA, & Alku & 4,53 & 4,86 & 4,06 & 3,71 & 0,071 & $* *$ & & $*$ \\
\hline & Keski & 4,63 & 5,18 & 4,44 & 3,87 & 0,176 & $*$ & & 0 \\
\hline & Loppu & 6,11 & 4,12 & 5,72 & 2,99 & 0,221 & $*$ & $* *$ & \\
\hline & Keskim. & 5,38 & 4,62 & 5,03 & 3,38 & 0,124 & $* *$ & $* *$ & $*$ \\
\hline \multirow[t]{4}{*}{ Väkirehu, kg KA, } & Alku & 2,02 & 2,02 & 2,02 & 2,02 & & & & \\
\hline & Keski & 2,53 & 2,53 & 2,53 & 2,53 & & & & \\
\hline & Loppu & 3,02 & 5,84 & 3,02 & 5,92 & 0,026 & & $* * *$ & \\
\hline & Keskim. & 2,69 & 3,94 & 2,69 & 4,19 & 0,091 & & $* * *$ & \\
\hline \multicolumn{2}{|c|}{ Kivennäinen, kg KA } & 0,146 & 0,150 & 0,146 & 0,148 & 0,0015 & & & \\
\hline \multicolumn{2}{|l|}{ Vitamiini, kg KA } & 0,022 & 0,023 & 0,022 & 0,023 & 0,0001 & & & \\
\hline \multirow[t]{4}{*}{$\mathrm{Kg} \mathrm{KA}$, } & Alku & 6,71 & 7,04 & 6,25 & 5,90 & 0,071 & $* *$ & & $*$ \\
\hline & Keski & 7,33 & 7,88 & 7,13 & 6,57 & 0,176 & $*$ & & 0 \\
\hline & Loppu & 9,30 & 10,13 & 8,91 & 9,08 & 0,234 & o & & \\
\hline & Keskim. & 8,23 & 8,72 & 7,88 & 7,74 & 0,068 & $* *$ & 0 & $*$ \\
\hline \multirow{2}{*}{$\begin{array}{l}\text { Raakavalkuainen, g } \\
\text { NDF, g }\end{array}$} & \multicolumn{2}{|c|}{1449} & 1543 & 1274 & 1296 & 14,2 & $* * *$ & $*$ & 0 \\
\hline & \multicolumn{2}{|c|}{3508} & 3383 & 3147 & 2696 & 48,7 & $* *$ & $* *$ & $*$ \\
\hline RY & \multicolumn{2}{|c|}{8,23} & 8,86 & 7,39 & 7,57 & 0,076 & $* * *$ & $*$ & 0 \\
\hline OIV,g & \multicolumn{2}{|c|}{775} & 847 & 727 & 754 & 6,1 & $* *$ & $* *$ & $*$ \\
\hline
\end{tabular}

${ }^{1}$ Keskiarvon keskivirhe. $\quad{ }^{2}$ o $\mathrm{P}<0,10 ; * \mathrm{P}<0,05 ; * * \mathrm{P}<0,01 ; * * * \mathrm{P}<0,001$.

Tavoiteteuraspainoa 350 kiloa ei saavutettu millään käsittelyllä. NSR-ruhojen keskimääräiseksi teuraspainoksi muodostui 339 kiloa ja OHSR-ruhojen 320 kiloa ( $<<0,10$, Taulukko 3). NSR-sonnit teurastettiin keskimäärin kuusi viikkoa aiemmin kuin OHSR-sonnit $(\mathrm{P}<0,01,432$ vs. 474). Viimeiset sonnit teurastettiin heinäkuun loppupuolella eli 23.7. 5 kpl, 29.7. 12 kpl ja 30.7. 1 kpl. Näistä 13 oli OHSR-ruokinnalla ja 5 NSR-ruokinnalla. OHSR-sonnien kasvatuskausi olisi siten muodostunut vielä toteutunutta huomattavasti pidemmäksi, mutta viimeiset sonnit jouduttiin teurastamaan ennenaikaisesti rehun lämpenemisen, pilaantumisen ja siitä johtuvan niukkuuden takia kuin myös tuotantotilojen 
puhdistuksen johdosta. Vaikka R-sonnien kasvu loppujaksolla olikin N-sonneja parempaa, erityisesti NSR-ruokinnalla, ei ero intensiteetin välillä muodostunut tilastollisesti merkitseväksi $(\mathrm{P}=0,10,1511$ vs. 1273 g/pv). NSR-sonnit kasvoivat keski- ja loppujaksoilla OHSR-sonneja paremmin (K: $\mathrm{P}<0,01$, 1441 vs. 1217 g/pv ja L: P<0,05, 1597 vs. 1187 g/pv). Koko kaudelle laskettuna NSR-sonnit kasvoivat päivässä 273 g paremmin $(\mathrm{P}<0,05)$ kuin OHSR-sonnit. Teurasprosentti oli keskimäärin 53,4 (SD 1,50). NSR-ruhot luokitettiin lihakkaammiksi kuin OHSR-ruhot $(\mathrm{P}<0,05,7,1$ vs. 6,7), rasvaisuudessa ero oli suuntaa antava $(\mathrm{P}<0,10,3,6$ vs. 3,0). Lisäkasvukiloon sonnit käyttivät keskimäärin 6,4 (SD 0,86) kuiva-ainekiloa, nettokasvukiloa kohden laskettuna rehun muuntosuhde oli OHSR-sonneilla hieman heikompi kuin NSR-sonneilla ( $\mathrm{P}<0,10,12,1$ vs. 10,5 kg KA).

Taulukko 3. Sonnien kasvu, teurastulokset ja rehun muuntosuhde.

\begin{tabular}{|c|c|c|c|c|c|c|c|c|}
\hline \multirow{2}{*}{$\begin{array}{l}\text { Karkearehu (K) } \\
\text { Intensiteetti (I) }\end{array}$} & \multicolumn{2}{|c|}{ Nurmisäilörehu } & \multicolumn{2}{|c|}{ Seossäilörehu } & \multirow[b]{2}{*}{ SEM $^{1}$} & \multicolumn{3}{|c|}{ Merkitsevyys $^{2}$} \\
\hline & Niukka & Runsas & Niukka & Runsas & & $\mathrm{K}$ & I & $\mathrm{K}^{*} \mathrm{I}$ \\
\hline Eläinten lukumäärä & 8 & $8^{a}$ & 8 & $8^{\mathrm{ad}}$ & & & & \\
\hline Kokeen alussa, kg & 271 & 271 & 271 & 271 & 22,4 & & & \\
\hline Kokeen lopussa, kg & 627 & 638 & 607 & 599 & $8,4-9,1$ & $*$ & & \\
\hline Teuraspaino, kg & 337 & 342 & 321 & 320 & $6,8-7,4$ & 0 & & \\
\hline Ikä alussa, pv & 178 & 178 & 184 & 195 & 5,9 & & & \\
\hline Ikä lopussa, pv & 447 & 416 & 473 & 474 & $7,2-7,8$ & $* *$ & & \\
\hline Kokeen kesto, pv & 269 & 237 & 290 & 280 & $11,0-11,9$ & o & & \\
\hline Loppujakson kesto, pv & 129 & 97 & 150 & 140 & $11,0-11,9$ & o & & \\
\hline Kasvu, Alkujakso, g/pv & 1090 & 1290 & 1088 & 1015 & $79,5-85,9$ & & & \\
\hline Keskijakso, g/pv & 1379 & 1502 & 1256 & 1179 & $33,8-36,5$ & $* *$ & & $*$ \\
\hline Loppujakso, g/pv & 1409 & 1784 & 1137 & 1237 & $107,8-116,5$ & $*$ & & \\
\hline Kokeessa, g/pv & 1330 & 1558 & 1163 & 1180 & $59,3-64,1$ & $*$ & & \\
\hline Nettokasvu, g/pv & 752 & 875 & 641 & 664 & $35,7-38,6$ & $*$ & & \\
\hline Teuras-\% & 53,7 & 53,5 & 52,9 & 53,4 & $0,64-0,69$ & & & \\
\hline Lihakkuus $^{4}$ & 7,1 & 7,1 & 6,9 & 6,5 & $0,14-0,15$ & $*$ & & \\
\hline Rasvaisuus $^{5}$ & 3,3 & 3,9 & 3,0 & 3,0 & $0,26-0,28$ & 0 & & \\
\hline Kg KA / lisäkasvu-kg & 6,2 & 5,6 & 6,9 & 6,6 & $0,41-0,44$ & & & \\
\hline Kg KA / nettokasvu-kg & 11,0 & 10,0 & 12,5 & 11,8 & $0,60-0,65$ & o & & \\
\hline
\end{tabular}

${ }^{1}$ Keskiarvon keskivirhe.

2 o $\mathrm{P}<0,10$; * $\mathrm{P}<0,05$; ** $\mathrm{P}<0,01$; *** $\mathrm{P}<0,001$.

${ }^{3}$ Nettokasvua laskettaessa alkupainon teuras-\%:na käytetty 50.

${ }^{4}$ EUROP-luokitus: O-=4, O=5, O+=6, R-=7, R=8, R+=9.

${ }^{5}$ EUROP-luokitus: 2=vähäinen, 3=keskinkertainen, 4=rasvainen.

${ }^{a}$ Yksi eläin puhaltui 25.4.2003 ja poistettiin kokeesta samana päivänä, teuraaksi 15.5.2003.

${ }^{\mathrm{an}}$ Yksi eläin puhaltui ja kuoli 28.10.2002.

Taulukko 4. Dieetin orgaanisen aineen (OA), proteiinin ja NDF:n sulavuus ja sulavuuden muutos.

\begin{tabular}{|c|c|c|c|c|c|c|c|c|c|}
\hline \multirow{2}{*}{\multicolumn{2}{|c|}{$\begin{array}{l}\text { Karkearehu (K) } \\
\text { Intensiteetti (I) }\end{array}$}} & \multicolumn{2}{|c|}{ Nurmisäilörehu } & \multicolumn{2}{|c|}{ Seossäilörehu } & \multirow[b]{2}{*}{ SEM $^{1}$} & \multicolumn{3}{|c|}{ Merkitsevyys ${ }^{2}$} \\
\hline & & Niukka & Runsas & Niukka & Runsas & & K & I & $\mathrm{K}^{*} \mathrm{I}$ \\
\hline \multirow{3}{*}{$\begin{array}{l}\text { Ryhmiä } \\
\text { OA, }\end{array}$} & & 2 & 2 & 2 & 2 & & & & \\
\hline & Keskijakso & 78,8 & 79,4 & 69,3 & 69,2 & 0,42 & $* * *$ & & \\
\hline & Loppujakso & 76,0 & 71,7 & 69,1 & 67,4 & 0,27 & $* * *$ & $* *$ & $*$ \\
\hline \multirow[t]{2}{*}{ Proteiini, } & Keskijakso & 76,0 & 75,6 & 70,0 & 69,5 & 0,91 & $* *$ & & \\
\hline & Loppujakso & 73,8 & 67,1 & 68,6 & 65,0 & 1,07 & $*$ & $*$ & \\
\hline \multirow[t]{2}{*}{ NDF, } & Keskijakso & 74,2 & 75,9 & 50,4 & 49,6 & 0,79 & $* * *$ & & \\
\hline & Loppujakso & 67,4 & 55,5 & 49,2 & 37,0 & 0,62 & $* * *$ & $* * *$ & \\
\hline \multicolumn{10}{|c|}{ Muutos keskijaksolta loppujaksolle } \\
\hline \multicolumn{2}{|l|}{$\mathrm{OA}$} & $-2,76$ & $-7,67$ & $-0,24$ & $-1,77$ & 0,641 & $* *$ & $*$ & 0 \\
\hline \multicolumn{2}{|c|}{ Proteiini } & $-2,18$ & $-8,51$ & $-1,47$ & $-4,56$ & 1,214 & & $*$ & \\
\hline \multicolumn{2}{|l|}{ NDF } & $-6,85$ & $-20,37$ & $-1,27$ & $-12,58$ & 0,763 & $* *$ & $* * *$ & \\
\hline
\end{tabular}

\footnotetext{
${ }^{1}$ Keskiarvon keskivirhe.

${ }^{2}$ o $\mathrm{P}<0,10$; * $\mathrm{P}<0,05$; ** $\mathrm{P}<0,01$; *** $\mathrm{P}<0,001$.
} 
Dieetin orgaanisen aineen (OA), proteiinin ja ND-kuidun sulavuus oli keskijaksolla OHSR-ruokinnalla heikompaa kuin NSR-ruokinnalla (OA: $\mathrm{P}<0,001,79,1$ vs. 69,3; Prot: $\mathrm{P}<0,01,75,8$ vs. 69,8, NDF: $\mathrm{P}<0,001,75,0$ vs. 50,0, Taulukko 4). Loppukaudella R-ruokinta heikensi kaikkien edellä mainittujen muuttujien sulavuutta, eniten ND-kuidun ( $\mathrm{P}<0,001,58,3$ vs. 46,2). ND-kuidun sulavuus heikkeni eniten NRS-R-ruokinnalla siirryttäessä keskijaksolta loppujaksolle, yli 20 \%-yksikköä.

\section{Johtopäätökset}

Toisin kuin hankkeen ensimmäisessä osakokeessa, runsas väkirehuruokinta loppukasvatusvaiheessa paransi sonnien kasvua tässä kokeessa vain hieman. Loppukauden voimakkaampi väkirehuruokinta ei vaikuttanut haitallisesti eläinten terveyteen. Herneen osuus seoskasvustossa oli melko alhainen, mikä oli seurausta herneen kylvömäärästä. Seossäilörehulla ei päästy nurmisäilörehua vastaaviin tuotantotuloksiin. Merkittävin syy tähän oli seosrehun nurmisäilörehua alhaisempi D-arvo eli sulavuus. Seossäilörehua saaneiden sonnien heikkoon kasvuun erityisesti kokeen loppuvaiheessa vaikutti todennäköisesti myös heinäkuun hellejakso ja sen johdosta heikentynyt syönti. Nurmisäilörehun voimakas voihappokäyminen saattoi toisaalta heikentää rehun syöntiä ja siten kasvua koko kokeen aikana, vaikkakin kasvu nurmisäilörehulla muodostui kohtuullisen hyväksi.

Kiitokset Suomen Rehu Oy:lle kokeeseen toimitetusta valkuaistäydennysrehusta sekä MTT:n emolehmänavetan EMO-tiimille kokeen huolellisesta toteutuksesta.

\section{Kirjallisuus}

European Commission. 1971. Commission Directive 71/250/EEC. Determination of ash which is insoluble in hydrochloric acid. Official Journal No L 155/13, 30-31 (Method B).

Friedel, K. 1990. Die Schätzung des energetischen Futterwertes von Grobfutter mit Hilfe einer

Cellulasemethode. [The estimation of the energetic feeding value of roughages by means of cellulase method]. Wissenschaftliche Zeitschrift Universitet Rostock, N-Reihe 39, 78-86.

Joki-Tokola, E., Huuskonen, A., Huttu, S. \& Kiljala, J. 2002. Rehuvirna lihanautojen kokoviljasäilörehuruokinnassa. In: Maataloustieteen Päivät 2002, Kotieläintiede, 9.-10.1.2002 Viikki, Helsinki. MKL:n julkaisuja nro 977. s. 196. http://www.agronet.fi/maataloustieteellinenseura/julkaisut/poste/kr23joki.pdf

Kiljala, J. Isolahti, M., Huuskonen, A. \& Joki-Tokola, E. 2004. Palkoviljat kokoviljasäilörehun raakaaineena. In: Maataloustieteen Päivät 2004, 12-13.1.2004 Viikki, Helsinki. Suomen Maataloustieteellisen Seuran tiedote no 19. http://www.agronet.fi/maataloustieteellinenseura/julkaisut/posterit04/kr22.pdf

Koho, N., Pösö, R., Soveri, T., Rytkönen, A.-K., Manninen, M. \& Jauhiainen, L. 2004. Väkirehun

koostumus ja intensiteetti hereford-sonnien loppukasvatuksessa. c) Eläinten hyvinvointi. In: Maataloustieteen Päivät 2004, 12-13.1.2004 Viikki, Helsinki. Suomen Maataloustieteellisen Seuran tiedote no 19.

http://www.agronet.fi/maataloustieteellinenseura/julkaisut/posterit04/kh05.pdf

Manninen, M., Ruusunen, M., Pösö, R., Soveri, T., Jauhiainen, L. \& Suvitie, M. 2004. Väkirehun

koostumus ja intensiteetti hereford-sonnien loppukasvatuksessa. a) Tuotanto sekä ruhon ja lihan laatu. In: Maataloustieteen Päivät 2004, 12-13.1.2004 Viikki, Helsinki. Suomen Maataloustieteellisen Seuran tiedote no 19. http://www.agronet.fi/maataloustieteellinenseura/julkaisut/posterit04/kr13.pdf

Morris T.R. 1999. Experimental Design and Analysis in Animal Sciences. CABI Publishing, Wellington, UK. $134 \mathrm{p}$.

McCleary, B.V., Solah, V. \& Gibson, T.S. 1994. Quantitative measurement of total starch in cereal flours and products. J. Cereal Sci. 20: 51-58.

Nykänen, A., Leinonen, P. \& Nykänen-Kurki, P. 2001. Havaintoja yksi- ja monivuotisista nurmipalkokasveista luomuviljelyssä. Suomen Nurmiyhdistyksen julkaisu 14: 41-48.

Pihamaa, P., Juntti, L., Manninen, M., Heikkilä, A.-M. \& Jauhiainen, L. 2004. Väkirehun koostumus ja intensiteetti hereford-sonnien loppukasvatuksessa. e) Tuotannon talous. In: Maataloustieteen Päivät 2004, 12 13.1.2004 Viikki, Helsinki. Suomen Maataloustieteellisen Seuran tiedote no 19.

http://www.agronet.fi/maataloustieteellinenseura/julkaisut/posterit04/kr15.pdf

Pösö, R., Koho, N., Manninen, M. \& Jauhiainen, L. 2004. Väkirehun koostumus ja intensiteetti herefordsonnien loppukasvatuksessa. b) Veren koostumuksen muutokset kasvatuksen aikana. In: Maataloustieteen Päivät 2004, 12-13.1.2004 Viikki, Helsinki. Suomen Maataloustieteellisen Seuran tiedote no 19.

http://www.agronet.fi/maataloustieteellinenseura/julkaisut/posterit04/kr14.pdf

SAS. 1999. SAS/STAT User's Guide, Version 8, Cary, NC: SAS Institute Inc. 3809 p.

Soveri, T., Glad, T., Kujala, M., Koho, N., Pösö, R. \& Manninen, M. 2004. Väkirehun koostumus ja intensiteetti hereford-sonnien loppukasvatuksessa. d) Sorkkaterveys. In: Maataloustieteen Päivät 2004, 12 13.1.2004 Viikki, Helsinki. Suomen Maataloustieteellisen Seuran tiedote no 19. 
http://www.agronet.fi/maataloustieteellinenseura/julkaisut/posterit04/kh06.pdf Syrjälä-Qvist, L. 1986. Palkokasvien käyttö rehuna. SITRA Biologisen typensidonnan ja ravinnetypen hyväksikäytön projekti. Tietolehtinen 7. 7 p.

Tuori, M., Kaustell, K., Valaja, J., Aimonen, E., Saarisalo, E. \& Huhtanen, P. 2002. Rehutaulukot ja ruokintasuositukset. Helsinki. 88 p.

Van Soest, P.J., Robertson, J.B. \& Lewis, B.A. 1991. Methods for dietary fiber, neutral detergent fiber and nonstarch polysaccharides in relation to animal nutrition. J. Dairy Sci. 74: 3583-3597. 